\title{
Effect of an educational program on awareness of cervical cancer and uptake of Pap smear among market women in Niger State, North Central Nigeria
}

\author{
Gana, G. J. ${ }^{1 \star}$, Oche, M. 0. ${ }^{1,2}$, Ango, J. T. ${ }^{1}$, Raji, M. O. ${ }^{1,2}$ and Okafoagu, N. C. ${ }^{1}$ \\ ${ }^{1}$ Usmanu Danfodiyo University Teaching Hospital, Sokoto, Sokoto State, Nigeria. \\ ${ }^{2}$ Usmanu Danfodiyo University, Sokoto, Sokoto State, Nigeria.
}

Received 14 July, 2016; Accepted 25 August, 2016

\begin{abstract}
Cervical cancer is an important but preventable public health problem among women worldwide. Studies have shown low awareness about cervical cancer and its screening test. The aim of this research was to determine the effectiveness of an educational intervention programme on awareness of cervical cancer and uptake of Pap smear by women in selected markets in Niger State, Nigeria. This was a quasi-experimental study conducted in 2014. Sample size was determined based on a previous study on Pap smear test in Nigeria. Multi stage sampling technique was used for recruiting the study participants. SPSS statistical software was used for data entry, editing and analysis. The sociodemographic profile of the respondents was comparable between both groups. Respondents' awareness about cervical cancer and uptake of Pap smear were comparable between both groups at pre-intervention. Post-intervention, there was a statistically significant difference in awareness about cervical cancer $\left(X^{2}=59.127, p<0.001\right)$ with a marginal increase in uptake of Pap smear test (Fisher's exact, $p=0.621$ ) in the intervention group as compared to the control group. This finding underscores the need for awareness creation strategies and the need for more interventional programs.
\end{abstract}

Key words: Pap smear test, human papilloma virus, cervical cancer.

\section{INTRODUCTION}

Cervical cancer is the commonest genital tract malignancy in females and second overall to breast cancer in the developing world (Budukh et al., 2001; Mutyaba et al., 2006; Ezem, 2007). Cervical cancer is an important but preventable public health problem among women worldwide (Budukh et al., 2001; Parkin et al., 2005; Arulogun and Maxwell, 2012). It poses a serious public health threat to women in many low and medium resource countries in South and Central America, subSaharan Africa, South and Southeast Asia where it is still the leading type of cancer among women (Budukh et al., 2001; Arulogun and Maxwell, 2012).

Worldwide, about 500,000 new cases are diagnosed every year, and more than $80 \%$ of these occur in developing countries (WHO, 2004; Hoque et al., 2008; Hoque and Hoque, 2009; Wright et al., 2011). In Nigeria,

*Corresponding author. E-mail: gojigan2001@gmail.com. Tel: +234 8035927162.

Author(s) agree that this article remain permanently open access under the terms of the Creative Commons Attribution License 4.0 International License 
9900 cases occur annually (WHO/ICO Information Centre on HPV and Cervical Cancer (HPV Information Centre), 2010). Incidence rates are $16.7 / 100,000$ women worldwide, $17.8 / 100,000$ in West Africa and 16.7/100,000 in Nigeria (WHO/ICO Information Centre on HPV and Cervical Cancer (HPV Information Centre), 2010). Worldwide mortality figure is estimated at about 300,000 deaths annually, $85 \%$ are said to occur in developing countries (WHO, 2004; Hoque et al., 2008; Hoque and Hoque, 2009). Nigerian annual mortality is estimated at about 8020 deaths (WHO/ICO Information Centre on HPV and Cervical Cancer (HPV Information Centre), 2010). Mortality rates are reportedly $8.9 / 100,000$ worldwide; and $13.5 / 100,000$ in Nigeria (WHO/ICO Information Centre on HPV and Cervical Cancer (HPV Information Centre), 2010).

Many factors have been implicated in the development of cervical cancer. They include infection with high risk human papilloma virus (HPV type 16 and 18), early sexual debut, high parity, multiple sexual partners, coinfection with human immunodeficiency virus type-2, immunosuppresants and certain dietary deficiencies are all known to be associated risk factors for cervical cancer (World Health Organization, 2002). Studies have shown that human papilloma virus infection is responsible for more than $90 \%$ of the cases of invasive cervical cancer worldwide, and it is related to $80 \%$ of pre-cancerous changes in the cervix (Terefe and Gaym, 2008; Wong et al., 2009).

A study by Bosch and de Sanjose in 2007 showed that more than $99 \%$ of cases of cervical cancer worldwide are estimated to contain HPV DNA (Nasiell et al., 1986). HPV infects the cells of the cervix and slowly causes precancerous cellular changes (dysplasia) that can progress to cancer. Though primary prevention strategies such as HPV vaccination are beginning to show a lot of promise in developed countries, secondary prevention which involves using relatively cheap cervical cancer cytological screening (Pap smear) test has been found to be the most cost effective screening test (Chirenje et al., 2001).

Systematically organized population based programmes have been found useful in preventing cervical cancer (Serraino et al., 2002). The use of Pap smear to screen for cervical cancer led to the fall in incidence of cancer of the cervix by $70-90 \%$ in highly screened populations in some industrialized countries (Wong et al., 2009). In the United States of America for instance, the introduction of the Pap smear has been responsible for a $90 \%$ decrease in deaths from cervical cancer (Eddy, 1990). Likewise in Australia, deaths from cervical cancer have steadily decreased, at about $2.8 \%$ a year, since the introduction of the National Cervical Cancer Screening Program in 1991 (Wong et al., 2009).

In Nigeria, though there is a national guideline for cervical cancer screening program in the country, there is no effective cervical cancer screening program in place.
Hitherto, about $75 \%$ of patients in Nigeria present at an advanced stage (stage 3 or 4) with bad survival prognosis, which is the inverse of presentations in developed countries where $75 \%$ present early and prognosis of survival is better (Aboyeji et al., 2005). Studies have shown poor knowledge about cervical cancer (Audu et al., 1999; Feyi-Waboso et al., 2005; Ayinde et al., 2006), and poor acceptance and underutilization of the screening test (Ayinde et al., 2004; Ezem, 2007; Wright et al., 2011; Hyacinth et al., 2012). A study done by Wright et al. (2011) in Lagos showed that only $14.9 \%$ of a group of market women had heard of cervical cancer while another study among female health workers in llorin showed that only $0.3 \%$ of the respondents had ever been screened (Aboyeji et al., 2005; Wright et al., 2011). This raises questions on the situation of things in northern Nigeria if the south-western part of the country which usually has better health indices have these findings.

It has been shown that the more the number of screening a woman has had in her lifetime, the higher the degree of protection she derives from the process (Wright et al., 2011). Thus, 1-2 yearly screening has been shown to reduce the incidence of cervical cancer by $93 \%$; this figure reduces to $83 \%$ where screening is done every 5 years (Miller, 1992; Wright et al., 2011). Even a single Pap smear in a woman's lifetime between the ages of 40 -50 years can reduce her risk of an invasive disease by $25 \%$ (Gamarra et al., 2005).

It is believed that the knowledge, attitude and practice among market women who belong to different faiths, diverse tribal and socio-cultural backgrounds will be largely representative of most of the women groups found in the state hence their selection as a target for health education. It is therefore hoped that health educating these market women would have a positive impact on their attitude to cervical cancer screening with subsequent improvement in utilization of available screening services and therefore improve the quality of life of women.

Furthermore, considering their diverse backgrounds they would serve as positive agents of change as they would have appropriate knowledge to create awareness on cervical cancer risk factors, Pap smear screening benefits and place to access the screening service to their peers. As such, two important outcomes would have been achieved. The aim of this study was to provide information on the effectiveness of an educational intervention programme on awareness of cervical cancer and uptake of Pap smear by market women to aid the institution of an effective cervical cancer screening program in Nigeria.

\section{MATERIALS AND METHODS}

\section{Background information on study area}

Niger state occupies about $8 \%$ of Nigeria's landmass. It had a 
population of 3,950,249 people (2006 census) and an estimated projected population of over 5 million people for 2016. By reason of its location, climate and soil type, the state is one of the largest and most fertile agriculture lands in the country and has the capacity to produce most of Nigeria's stable crops. It also has ample opportunities for grazing, fishing and forestry. The state has a rich network of markets in all the LGAs because of the bountiful agricultural produce yearly.

\section{Study design}

This was a quasi-experimental study design comparing market women in health zone A (intervention group) with market women in health zone B (control group) (with pre and post intervention data collection) in Niger state. The state is divided into three health zones, two health zones were selected by simple random sampling and randomly assigned as intervention and control groups by balloting. This meant that individual subjects did not have the privilege of being randomly assigned into either study group (individual randomization) rather block randomization was done. Market women who were registered with the selected market associations and had market stalls/space were those considered eligible to be enrolled into the study.

\section{Sample size determination}

Sample size was determined based on a previous study on Pap smear test in Nigeria (Kabir et al., 2005). A minimum sample size of 84 was obtained for each group (intervention and control), a correction for non-response was done and 93 participants were enrolled per group. The level of significance was set at $5 \%(\alpha=$ 0.05 ) and the power of the study was set at $80 \%=0.8$.

\section{Sampling method}

Multi stage sampling technique was used for recruiting the study participants into the study groups. Stage 1: Two health zones were selected from the three in the state using simple random sampling and randomly assigned as the intervention and control groups. Stage 2: One local government area (LGA), each was selected from each of the selected health zones using simple random sampling. Stage 3: Three wards with markets were eventually selected from each selected LGA. Stage 4: Participants were recruited using systematic random sampling into the intervention and control group using the sampling interval (number of eligible market women in each market divided by the proportional allocation of market women to be selected from each market).

\section{Data collection method}

The study was carried out in three phases. The pre-intervention phase, baseline information on awareness of cervical cancer and uptake of screening test was collected from participants (intervention and control groups) by trained interviewers using an interviewer administered questionnaire. During the intervention phase, health education was provided on cervical cancer, Pap smear test with emphasis on its benefit and procedure and on proximate health institutions that provide such services to the intervention group. In addition, IEC materials were designed to stimulate increased awareness on cervical cancer and Pap smear test in English and local languages (Nupe and Hausa) for the intervention group. A total of three such meetings were held at the market, in groups to capture the different sections of the market usually between $10 \mathrm{am}$ and 12 noon before activities peak at the respective markets. A post-intervention survey was conducted three months post-intervention on both groups, using the same instrument, and research assistants who administered the preintervention questionnaires to reduce interviewer bias. After postintervention data collection, the control group was also given a series of health education intervention to enable them benefit from the essence of the study.

\section{Data analysis}

The questionnaires were manually checked for completeness. Data were then entered directly into SPSS version 20.0. Data editing and cleaning was performed before data analysis began. This was done to correct errors that may have occurred during data collection and entry. The data editing was performed by running frequencies and descriptive statistics for all variables.

Dependent variables include: pre intervention knowledge of risk factors and symptoms of cervical cancer, pre intervention attitude of respondents to cervical cancer, uptake rate of Pap smear test. Independent variables include: age, marital status, tribe and level of education.

The proportion of the respondents who knew about the risk factors, symptoms, prevention and diagnosis of cervical cancer and knew about indication for Pap smear were used as indices for the measurement of knowledge of cervical cancer among the respondents. Descriptive analysis of data using mean and standard deviation for continuous numerical variables (respondents' age, number of children, knowledge score of cervical cancer, attitude score), counts and frequencies for qualitative variables (marital status, tribe, and educational status) was done. Bivariate analysis was done to compare variables between both groups at preintervention and between pre and post-test findings in both groups at the end of the study. The findings at post intervention in both groups were also compared. Chi square test was used to compare the similarity of the socio-demographic variables (age group, marital status, educational status, tribal distribution) in both groups preintervention. Chi square was also used to determine the association between respondents' knowledge, attitude, socio-demographic characteristics and uptake of Pap smear test in both groups pre and post intervention. Chi square was also used to compare the proportion of uptake of Pap smear, factors affecting uptake of Pap smear in both intervention and control group pre and post intervention. All the results were presented in form of tables and charts. All statistical tests were carried out as 2 tailed test with level of significance $(\alpha)$ set at 0.05 .

\section{Limitations of the study}

Inability to provide free Pap smear test screening however the test was provided at a subsidized rate.

\section{Ethical clearance}

The Research and Ethics Committee of the Usmanu Danfodiyo University Teaching Hospital approved the study protocol. Permission was sought from the Niger State Ministry of Health and the necessary market authorities and informed consent was obtained from the participants while confidentiality was assured.

\section{RESULTS}

Most of the respondents were within the age groups 35 to 54 years with a mean age of $38.54 \pm 11.06$ years and 
Table 1. Socio-demographic characteristics of the respondents.

\begin{tabular}{|c|c|c|c|}
\hline Variables & $\begin{array}{c}\text { Intervention group } \\
\mathrm{n}=93 ; \text { no. }(\%)\end{array}$ & $\begin{array}{l}\text { Control Group } \\
n=93 ; \text { no. (\%) }\end{array}$ & Test statistics \& P-value \\
\hline \multicolumn{4}{|l|}{ Age (years) } \\
\hline $18-24$ & $8(8.6)$ & $4(4.3)$ & \multirow{7}{*}{$\begin{array}{c}x^{2}=4.7 \\
p=0.323\end{array}$} \\
\hline $25-34$ & $27(29)$ & $18(19.4)$ & \\
\hline $35-44$ & $26(28)$ & $29(31.2)$ & \\
\hline $45-54$ & 20 (21.5) & $27(29)$ & \\
\hline$\geq 55$ & $12(12.9)$ & $15(16.1)$ & \\
\hline \multirow[t]{2}{*}{ Mean age \pm SD } & $38.54 \pm 11.06$ & $41.94 \pm 10.94$ & \\
\hline & & 41.95 & \\
\hline \multicolumn{4}{|l|}{ Marital Status } \\
\hline Single & $4(4.3)$ & $6(6.5)$ & \multirow{3}{*}{$\begin{array}{l}x^{2}=1.55 \\
p=0.461\end{array}$} \\
\hline Married & $86(92.5)$ & $81(87.1)$ & \\
\hline Widowed/ Divorced & $3(3.2)$ & $6(6.5)$ & \\
\hline \multicolumn{4}{|l|}{ Educational status } \\
\hline No formal education & $71(76.3)$ & $46(49.5)$ & \multirow{4}{*}{$\begin{array}{l}x^{2 *}=16.6 \\
p=0.001\end{array}$} \\
\hline Primary level & $15(16.1)$ & $23(24.7)$ & \\
\hline Secondary level & $6(6.5)$ & $18(19.4)$ & \\
\hline $\begin{array}{l}\text { Tertiary level } \\
\text { Respondents' living children }\end{array}$ & $1(1.1)$ & $6(6.5)$ & \\
\hline Mean \pm SD & $4.73 \pm 2.94$ & $5.33 \pm 2.97$ & $\mathrm{t}=1.387, \mathrm{df}=184, \mathrm{p}=0.167, \mathrm{Cl}=-0.254$ to 1.459 \\
\hline
\end{tabular}

Table 2. Awareness on cervical cancer.

\begin{tabular}{lcccc}
\hline \multirow{3}{*}{ Ever heard of cervical cancer } & \multicolumn{2}{c}{ Pre-intervention } & \multicolumn{2}{c}{ Post-intervention } \\
\cline { 2 - 5 } & $\begin{array}{c}\text { Intervention } \\
(\mathbf{n}=93) ; \text { No. }(\%)\end{array}$ & $\begin{array}{c}\text { Control } \\
(\mathbf{n}=93) ; \text { No. }(\%)\end{array}$ & $\begin{array}{c}\text { Intervention } \\
(\mathbf{n}=88) ; \text { No. }(\%)\end{array}$ & $\begin{array}{c}\text { Control } \\
(\mathbf{n}=87) ; \text { No. (\%) }\end{array}$ \\
\hline Yes & $14(15.10)$ & $20(21.5)$ & $63(71.6)$ & $19(21.80)$ \\
No & $79(84.90)$ & $73(78.50)$ & $25(28.4)$ & $68(78.20)$ \\
\hline
\end{tabular}

Fisher's exact, $p=0.343 ; x^{2}=59.127, p<0.001$.

$41.94 \pm 10.94$ years for the intervention and control groups, respectively. There was no statistically significant difference in the age group distribution of the two groups $\left(\mathrm{x}^{2}=4.7, \quad \mathrm{p}=0.323\right)$. The proportion of married respondents was similar in both groups $(92.5 \%$ in intervention and $87.1 \%$ in control groups, respectively). The proportion of those without any formal education was statistically significantly higher in the intervention group $\left(x^{2}=16.6, p<0.001\right)$; however, the mean respondents' children was similar in both groups $(t=1.387, \mathrm{Cl}=-0.254$ to $1.459, p=0.167$ ) (Table 1).

Pre-intervention, the awareness about cervical cancer was 15.10 and $21.50 \%$ in the intervention and control groups, respectively and the difference was not statistically significant (Fisher's exact, $\mathrm{p}=0.343$ ), while at post-intervention, it was 71.60 and $21.80 \%$ in the intervention and control groups, respectively and was statistically significant $\left(x^{2}=59.127, p<0.001\right)$ (Table 2). Respondents' friends were the single most important source of information about cervical cancer at the beginning of the study in both study groups (Figure 1). The mass media was the only source of information about Pap smear test in the intervention group while health workers $(42.9 \%)$ and relatives $(28.6 \%)$ were the main sources of information in the control group (Figure 2 ). Less than $10 \%$ of respondents had heard of Pap smear at the beginning of the study in both groups and the difference was not statistically significant while in post-intervention, $34.1 \%$ of respondents in the intervention group and $5.7 \%$ in the control group had heard of Pap smear test $\left(x^{2}=21.966, p<0.0001\right)$ (Table 3 ). Only $9.7 \%$ of the respondents in the intervention group and $8.6 \%$ of the respondents in the control group knew that early onset of sexual intercourse is a risk factor for cervical cancer ( $p=0.474$, (Fisher's exact). $11.8 \%$ of respondents in both groups knew that having multiple sexual partners is a risk factor of cervical cancer $\left(x^{2}=\right.$ $3.237, p=1.000) .7 .5 \%$ of respondents in the intervention 


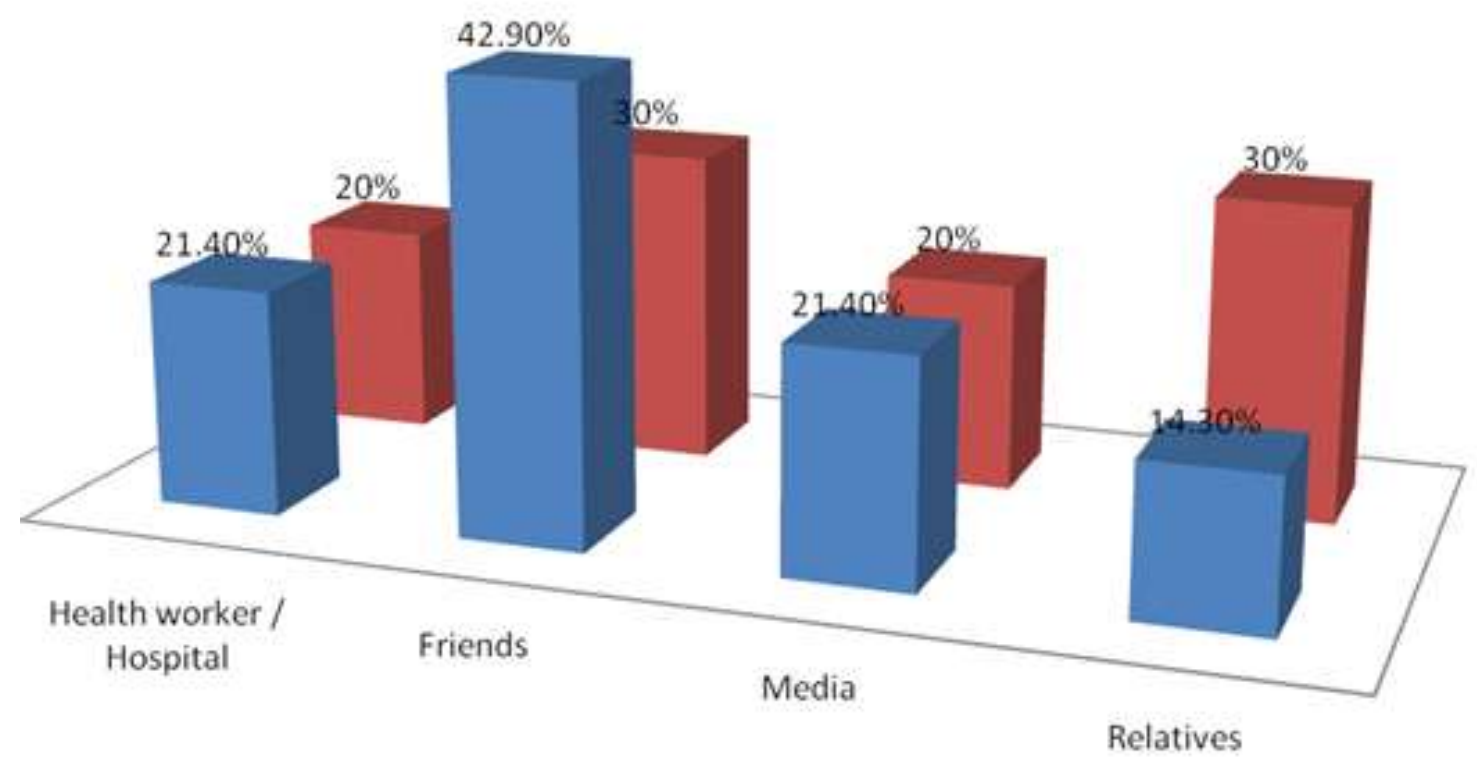

Figure 1. Respondents' sources of information on cervical cancer.

= Intervention group $=$ Control group

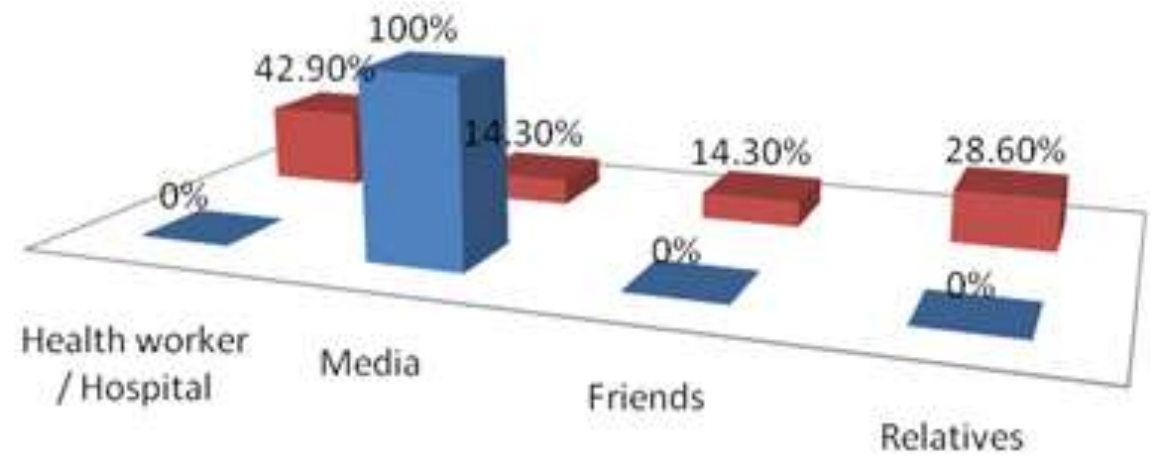

Figure 2. Sources of information about Pap smear test.

group and $5.4 \%$ of respondents in the control group knew that history of human papilloma virus infection was associated with cervical cancer $\left(x^{2}=5.116, p=0.164\right)$
(Table 4).

In post intervention, $55.7 \%$ of respondents in the intervention group and $9.2 \%$ of those in control group 
Table 3. Respondents' awareness about Pap smear test.

\begin{tabular}{llcccc}
\hline & & \multicolumn{3}{c}{ Group } \\
\cline { 3 - 5 } Variable & \multicolumn{2}{c}{ Pre-intervention } & \multicolumn{2}{c}{ Post-intervention } \\
\cline { 3 - 6 } & & Intervention & Control & Intervention & Control \\
& & $\mathrm{n}=93 ;$ No. $(\%)$ & $\mathbf{n}=93 ;$ No. $(\%)$ & $\mathbf{n = 8 8 ; ~ N o . ~ ( \% ) ~}$ & $\mathbf{n}=87 ;$ No. (\%) \\
\hline \multirow{2}{*}{ Have you ever heard of Pap smear test } & Yes & $1(1.1)$ & $7(7.5)$ & $30(34.1)$ & $5(5.7)$ \\
& No & $92(98.9)$ & $86(92.5)$ & $58(69)$ & $82(94.3)$ \\
\hline
\end{tabular}

$p=0.064$, Fisher's exact; $x^{2}=21.966, p<0.0001$.

Table 4. Comparative knowledge of risk factors among respondents in both groups pre and post intervention.

\begin{tabular}{|c|c|c|c|c|}
\hline \multirow[b]{2}{*}{ Variable } & \multicolumn{2}{|c|}{ Study group } & \multicolumn{2}{|c|}{ Control group } \\
\hline & $\begin{array}{c}\text { Pre- } \\
\text { intervention } \\
n=93 ; \text { No. (\%) }\end{array}$ & $\begin{array}{c}\text { Post- } \\
\text { intervention } \\
\mathrm{n=88;} \text { No. (\%) }\end{array}$ & $\begin{array}{c}\text { Pre- } \\
\text { intervention } \\
n=93 ; \text { No. (\%) }\end{array}$ & $\begin{array}{c}\text { Post- } \\
\text { intervention } \\
\mathrm{n}=87 ; \text { No. }(\%)\end{array}$ \\
\hline Early onset of sexual intercourse & $7(7.5)$ & $49(55.7)$ & $8(8.6)$ & $8(9.2)$ \\
\hline Test statistics and p-value & \multicolumn{2}{|c|}{$x^{2}=58, p<0.0001$} & \multicolumn{2}{|c|}{$x^{2}=9, p=0.253$} \\
\hline Multiple sexual partners & $11(11.8)$ & $60(68.2)$ & $11(11.8)$ & $14(16.1)$ \\
\hline Test statistics and $p$-value & \multicolumn{2}{|c|}{$x^{2}=57, p<0.0001$} & \multicolumn{2}{|c|}{$x^{2}=11, p=0.027$} \\
\hline Family history of cervical cancer & $8(8.6)$ & $48(54.5)$ & $12(12.9)$ & $8(9.2)$ \\
\hline Test statistics and p-value & \multicolumn{2}{|c|}{$x^{2}=57, p<0.0001$} & \multicolumn{2}{|c|}{$x^{2}=12, p=0.101$} \\
\hline Human papilloma virus infection & $7(7.5)$ & $25(28.4)$ & $5(5.4)$ & $8(9.2)$ \\
\hline Test statistics and p-value & \multicolumn{2}{|c|}{$x^{2}=56, p<0.0001$} & \multicolumn{2}{|c|}{$x^{2}=10, p=0.125$} \\
\hline High parity & $6(6.5)$ & $42(47.7)$ & $6(6.5)$ & $6(6.9)$ \\
\hline Test statistics and p-value & \multicolumn{2}{|c|}{$x^{2}=58, p<0.0001$} & \multicolumn{2}{|c|}{$x^{2}=11, p=0.276$} \\
\hline Vaginal bleeding after menopause & $6(6.5)$ & $48(54.5)$ & $11(11.8)$ & $12(13.8)$ \\
\hline Test statistics and $p$-value & \multicolumn{2}{|c|}{$x^{2}=58, p<0.0001$} & \multicolumn{2}{|c|}{$x^{2}=9, p=0.109$} \\
\hline Weight loss & $8(8.6)$ & $48(54.5)$ & $11(11.8)$ & $12(13.8)$ \\
\hline Test statistics and p-value & \multicolumn{2}{|c|}{$x^{2}=57, p<0.0001$} & \multicolumn{2}{|c|}{$x^{2}=10, p=0.075$} \\
\hline
\end{tabular}

$\mathrm{x}^{2}=$ McNemar Bowker test.

knew that early onset of sexual intercourse is a risk factor for cervical cancer $\left(x^{2}=250.655, p<0.0001\right), 68.2 \%$ of those in intervention group and $16.1 \%$ of those in control group knew that having multiple sexual partners is a risk factor of cervical cancer $\left(x^{2}=249.912, p<0.0001\right), 54.5 \%$ of those in intervention group and $13.8 \%$ of those in control group knew that vaginal bleeding after intercourse and weight loss were symptoms of cervical cancer $\left(x^{2}\right.$ $=257.63, p<0.0001)($ Table 5).

Only one respondent in both groups (1.1\%) had ever done Pap smear test before the study, while in postintervention, it was $3.4 \%$ of respondents in intervention group and $1.1 \%$ in the control group (Fisher's exact, $p=0.621$ ) (Table 6). The main reason for non-uptake of Pap smear test pre-intervention in both groups was "not being aware of the test" and finding was similar in both groups while in post-intervention, other significant contributing factors were: do not have time to do the test $(15.9 \%)$, not having symptoms $(13.6 \%)$, not feeling at risk of the disease $(11.5 \%)(p<0.0001$, Fisher's exact) (Table
7). A comparable proportion of respondents in both groups: $79.5 \%$ in intervention group and $79.3 \%$ in the control group expressed willingness to do a screening test for cervical cancer if it is beneficial and it is available (Table 8) and a comparable proportion were also willing to go for diagnostic tests if it is indicated (Table 9).

\section{DISCUSSION}

This study showed that only a fifth of respondents in both groups had ever heard of cervical cancer. This is quite similar to findings in a study on community education on cervical cancer among market women in Lagos where only $14.9 \%$ of respondents in the intervention group and $21.7 \%$ of those in the control group had ever heard of cervical cancer (Wright et al., 2010) but lower than findings in a study among market women in Ibadan where about $40.8 \%$ had heard about cervical cancer (Ayinde et al., 2006). This was because there was an on- 
Table 5. Post intervention knowledge of cervical cancer among study and control groups

\begin{tabular}{|c|c|c|}
\hline \multirow{2}{*}{ Variable } & \multirow{2}{*}{$\begin{array}{c}\text { Study group } \\
\text { Post-intervention } \\
\mathrm{n}=88 ; \text { No. }(\%)\end{array}$} & \multirow{2}{*}{$\begin{array}{c}\text { Control group } \\
\text { Post-intervention } \\
\mathrm{n}=87 ; \text { No. }(\%) \\
\end{array}$} \\
\hline & & \\
\hline Early onset of sexual intercourse & $49(55.7)$ & $8(9.2)$ \\
\hline Test statistics and p-value & $x^{2}=250.655$ & $p<0.0001$ \\
\hline Multiple sexual partners & $60(68.2)$ & $14(16.1)$ \\
\hline Test statistics and $p$-value & $x^{2}=249.912$ & $p<0.0001$ \\
\hline Family history of cervical cancer & $48(54.5)$ & $8(9.2)$ \\
\hline Test statistics and $p$-value & $x^{2}=259.742$ & $p<0.0001$ \\
\hline Human papilloma virus infection & $25(28.4)$ & $8(9.2)$ \\
\hline Test statistics and $p$-value & $x^{2}=261.873$ & $p<0.0001$ \\
\hline High parity & $42(47.7)$ & $6(6.9)$ \\
\hline Test statistics and p-value & $x^{2}=256.429$ & $p<0.0001$ \\
\hline Vaginal bleeding after menopause & $48(54.5)$ & $12(13.8)$ \\
\hline Test statistics and p-value & $x^{2}=264.7$ & $p<0.0001$ \\
\hline Weight loss & $48(54.5)$ & $12(13.8)$ \\
\hline Test statistics and $p$-value & $x^{2}=257.63$ & $p<0.0001$ \\
\hline
\end{tabular}

$x^{2}=$ Likelihood ratio Chi square test.

Table 6. Comparative Pap smear uptake pre and post-intervention.

\begin{tabular}{|c|c|c|c|c|}
\hline Variable & $\begin{array}{c}\text { Before } \\
\text { intervention }\end{array}$ & $\begin{array}{c}\text { Intervention group } \\
\mathrm{n}=93 ; \text { No }(\%)\end{array}$ & $\begin{array}{l}\text { Control group } \\
n=93 ; \text { No }(\%)\end{array}$ & $\begin{array}{c}\text { Test statistics and } P \text { - } \\
\text { value }\end{array}$ \\
\hline \multirow{5}{*}{$\begin{array}{l}\text { Have you ever done } \\
\text { Pap smear test }\end{array}$} & Yes & $1(1.1)$ & $1(1.1)$ & \multirow{2}{*}{$p=1.000$ (Fisher's exact) } \\
\hline & No & $92(98.9)$ & $92(98.9)$ & \\
\hline & $\begin{array}{c}\text { After } \\
\text { intervention }\end{array}$ & $\begin{array}{c}\text { Study group } \\
n=88\end{array}$ & $\begin{array}{c}\text { Control group } \\
n=87\end{array}$ & $\begin{array}{c}\text { Test statistics and } P \text { - } \\
\text { value }\end{array}$ \\
\hline & Yes & $3(3.4)$ & $1(1.1)$ & \multirow{3}{*}{$p=0.621$ (Fisher's exact) } \\
\hline & No & $85(96.6)$ & $86(98.9)$ & \\
\hline $\begin{array}{l}\text { Test statistics and } \mathrm{P} \text { - } \\
\text { value }\end{array}$ & & $\mathrm{p}=0.357$ (Fisher's exact) & $p=1.000$ (Fisher's exact) & \\
\hline
\end{tabular}

going awareness campaign about cervical cancer with free Pap smear screening at the time of the study (Ayinde et al., 2006). This means that awareness about cervical cancer is very low among the study subjects and is corroborated by studies done across various parts of the country.

Respondents' friends were the most important source of information on cervical cancer. Their friends and relatives were responsible for more than half of the respondents in both groups becoming aware of cervical cancer. This was corroborated by another study in Lagos which had similar findings (Wright et al., 2011). This finding highlights the gap in content of health education messages given by health workers when women go to health facilities for various reasons namely; antenatal care services, family planning services, immunization services for their under five children, consultations, bearing in mind that $92.5 \%$ of those in intervention group and $87.1 \%$ in control group were married. Health education and counselling sessions in hospitals need to incorporate messages on cervical cancer, its screening services and benefits of screening to improve awareness about the disease.

The awareness about Pap smear test was very poor, less than $10 \%$ of respondents in both groups had heard about it. This may have been because of the very low awareness about cervical cancer in the first place. Another study in Lagos had similar findings with $6.9 \%$ of respondents in intervention group and $12.0 \%$ of those in control group having heard of Pap smear test (Wright et al., 2011). This shows the extent of ignorance about preventive measures of common non-communicable 
Table 7. Reasons for lack of uptake of Pap smear test.

\begin{tabular}{lcccc}
\hline Why have you not done & \multicolumn{2}{c}{ Intervention group } & \multicolumn{2}{c}{ Control group } \\
\cline { 2 - 5 } Pap smear test & $\begin{array}{c}\text { Pre-intervention } \\
\mathbf{n = 9 2 ( \% )}\end{array}$ & $\begin{array}{c}\text { Post- } \\
\text { intervention } \\
\mathbf{n = 8 5 ( \% )}\end{array}$ & $\begin{array}{c}\text { Pre- } \\
\text { intervention } \\
\mathbf{n = 9 2 ( \% )}\end{array}$ & $\begin{array}{c}\text { Post-intervention } \\
\mathbf{n = 8 6 ( \% )}\end{array}$ \\
\hline Not feeling at risk of the & $3(3.3)$ & $11(12.5)$ & $4(4.3)$ & $4(4.6)$ \\
disease & $1(1.1)$ & $1(1.1)$ & $1(1.1)$ & $0(0)$ \\
Cultural or religious reasons & $3(3.3)$ & $12(13.6)$ & $2(2.2)$ & $2(2.3)$ \\
Do not have symptoms & $84(91.3)$ & $42(47.7)$ & $80(87)$ & $75(86.2)$ \\
Not aware of the test & $1(1.1)$ & $14(15.9)$ & $5(5.4)$ & $5(5.7)$ \\
Do not have time to do the & $0(0)$ & $3(3.4)$ & $0(0)$ & $0(0)$ \\
test & $0(0)$ & $2(2.3)$ & $0(0)$ & $0(0)$ \\
Test is expensive & & & \\
Fear of outcome of result & &
\end{tabular}

$p=0.539$, Fisher's exact; $p<0.0001$, Fisher's exact.

Table 8. Willingness to have a Pap smear test in future.

\begin{tabular}{|c|c|c|c|c|}
\hline Variable & $\begin{array}{c}\text { Before } \\
\text { intervention }\end{array}$ & $\begin{array}{l}\text { Intervention group } \\
\text { n = 93; No (\%) }\end{array}$ & $\begin{array}{l}\text { Control group } \\
\mathbf{n}=93 ; \text { No (\%) }\end{array}$ & $\begin{array}{c}\text { Test statistics and P. } \\
\text { value } \\
\end{array}$ \\
\hline \multirow{5}{*}{$\begin{array}{l}\text { Would you like to do the } \\
\text { screening test in the future }\end{array}$} & Yes & $67(72)$ & $72(77.4)$ & \multirow{2}{*}{$\begin{array}{c}\mathrm{P}=0.745 \text { (Fisher's } \\
\text { exact) }\end{array}$} \\
\hline & No & $26(28)$ & $21(22.6)$ & \\
\hline & $\begin{array}{c}\text { After } \\
\text { intervention }\end{array}$ & $\begin{array}{l}\text { Study group } \\
\mathrm{n}=88 \\
\end{array}$ & $\begin{array}{c}\text { Control group } \\
\mathrm{n}=87\end{array}$ & $\begin{array}{c}\text { Test statistics and P. } \\
\text { value } \\
\end{array}$ \\
\hline & Yes & $70(79.5)$ & $69(79.3)$ & \multirow{3}{*}{$\begin{array}{c}P=0.668 \text { (Fisher's } \\
\text { exact) }\end{array}$} \\
\hline & No & $18(20.5)$ & $18(20.7)$ & \\
\hline Test statistic & & $P=0.213$ (Fisher's exact) & $\mathrm{P}=0.927$ (Fisher's exact) & \\
\hline
\end{tabular}

Table 9. Willingness to go for further diagnostic tests if required.

\begin{tabular}{|c|c|c|c|c|}
\hline Variable & $\begin{array}{c}\text { Before } \\
\text { intervention }\end{array}$ & $\begin{array}{l}\text { Intervention group } \\
\text { n=93; No. (\%) }\end{array}$ & $\begin{array}{l}\text { Control group } \\
\text { n=93; No. (\%) }\end{array}$ & $\begin{array}{c}\text { Test statistics \& } \\
\text { P-value }\end{array}$ \\
\hline \multirow{6}{*}{$\begin{array}{l}\text { Would you go for further } \\
\text { tests if Pap smear shows } \\
\text { cancerous changes }\end{array}$} & Yes & $56(60.2)$ & $45(48.4)$ & $x^{2}=2.719$ \\
\hline & No & $37(39.8)$ & $48(51.6)$ & $p=0.254$ \\
\hline & & & & \\
\hline & After intervention & $\begin{array}{c}\text { Study group } \\
\mathrm{n}=88\end{array}$ & $\begin{array}{c}\text { Control group } \\
\mathrm{n}=87\end{array}$ & \\
\hline & Yes & $68(77.3)$ & $41(47.1)$ & $p=0.000$ (Fisher's \\
\hline & No & $20(22.7)$ & $46(52.9)$ & exact) \\
\hline Test statistics & & $\mathrm{p}=0.011$ (Fisher's exact) & $p=1.000$ (Fisher's exact) & \\
\hline
\end{tabular}

ailments that the women folk have. Consequently, the uptake rate of Pap smear test was just $1.1 \%$ in both study groups. This is better than that found in a study among female health workers in llorin where only $0.3 \%$ had ever done a Pap smear test (Aboyeji et al., 2005) though lower than what was seen in a female population group in Ibadan where about $5.6 \%$ of women had been screened previously (Ayinde et al., 2006). Among studies conducted in Nigeria, cervical cancer screening rates were highest among female health workers with uptake rates between 10 and 20\% (Anya et al., 2005; Kabir et al., 2005; Ojule et al., 2012; Hyacinth et al., 2012; Oche et al., 2013).

The main reason for non-uptake in this study and across other studies in the sub-region is lack of awareness on the test (Ayinde et al., 2006; Ezem, 2007; Wright et al., 2011). It is worth noting that more than three-quarters of respondents in both groups were willing to do a screening test for cervical cancer if they were told it exists and were informed of its benefits. This finding is 
similar to findings in another study in Lagos (Wright et al., 2011). These findings stress the need for awareness creation strategies and the need for more interventional programs.

This study was able to establish the benefits of an organized intervention program on awareness levels of market women about cervical cancer. On the whole, significant increase in awareness level of cervical cancer and Pap smear test attest to a favourable outcome following the intervention done in the experimental group.

\section{Conclusion}

This study showed an increased awareness about cervical cancer and Pap smear test; however, the uptake of Pap smear test remained low even after intervention. This may not be unconnected to the time bound nature of the study (6 months) and the limited contact time with the respondents (4 visits). There is a need to do larger scale interventions to improve awareness about cervical cancer and uptake of its screening test across the country.

\section{Conflict of interests}

The authors have not declared any conflict of interest.

\section{REFERENCES}

Aboyeji PA, ljaiya MDA, Jimoh AGA (2005). Knowledge, Attitude and Practice of Cervical Smear as a Screening Procedure for Cervical Cancer in Ilorin, Nigeria. Trop. J. Obstet. Gynaecol. 21(2):114.

Addah AO, Ojule JD, Fiebai PO (2012). Knowledge, attitude and practice of cervical cancer screening-Papanicolaou test (Pap smear) among female health care providers in Port Harcourt. Port Harcourt Med. J. 6(1):74-80

Anya SE, Oshi DC, Nwosu SO, Anya AE (2005). Knowledge, attitude, and practice of female health professionals regarding cervical cancer and Pap smear. Nig. J. Med. J. National Assoc. Resident Doctors Niger. 14(3):283-286.

Arulogun OS, Maxwell OO (2012). Perception and utilization of cervical cancer screening services among female nurses in University College Hospital, Ibadan, Nigeria. Pan Afr. Med. J. 11(1).

Audu M, EL-Nafaty AU, Khalil M, Jam Otubu B (1999). Knowledge and attitude to cervical cancer screening among women in Maiduguri, Nigeria. J. Obstet. Gynaecol. 19(3):295-297.

Ayinde OA, Ogunbode OO, Adebayo OJ (2006). Determinants of cervical cancer knowledge and the utilisation of screening among a Nigerian female population. Trop. J. Obstet. Gynaecol. 22(1):21.

Ayinde OA, Omigbodun AO, llesanmi AO (2004). Awareness of Cervical Cancer, Papanicolaou's Smear and Its Utilisation among Female Undergraduates in Ibadan. Afr. J. Reprod. Health 8(3):68-80.

Chirenje ZM, Rusakaniko S, Kirumbi L, Ngwalle EW, Makuta-Tlebere P, Kaggwa S, Mpanju-Shumbusho W, Makoae L (2001). Situation analysis for cervical cancer diagnosis and treatment in east, central and southern African countries. Bull. World Health Organ. 79(2):127132.
Eddy DM (1990). Screening for cervical cancer. Ann. Intern. Med. 113:214-216.

Ezem BU (2007). Awareness and uptake of cervical cancer screening in Owerri, South-Eastern Nigeria. Ann. Afr. Med. 6(3):94-98.

Feyi-Waboso PA, Kamanu C, Aluka C (2005). Awareness and risk factors for cervical cancer among women in Aba, South-Eastern

Nigeria. Trop. J. Obstet. Gynaecol. 22(1):25-26.

Gamarra CJ, Paz EP, Griep RH (2005). Knowledge, attitudes and practice related to Papanicolaou smear test among Argentina's women. Rev. Saude Publica 39(2):270-276.

Hoque E, Hoque M (2009). Knowledge of and attitude towards cervical cancer among female university students in South Africa. S. Afr. J. Epidemiol. Infect. 24(1):21-24

Hoque M, Hoque E, Kader SB (2008). Evaluation of cervical cancer screening program at a rural community of South Africa. East Afr. J. Public Health 5(2):111-116.

Hyacinth HI, Adekeye OA, Ibeh JN, Osoba T (2012). Cervical cancer and pap smear awareness and utilization of pap smear test among Federal civil servants in North Central Nigeria. PloS one 7(10).

Kabir M, lliyasu Z, Abubakar IS, Mahboob S (2005). Awareness and Practice of Cervical Cancer Screening among Female Health Professionals in Murtala Mohammed Specialist Hospital, Kano. Nigerian Postgrad. Med. J. 12(3):179-182.

Miller AB (1992). Cervical cancer screening programmes: management guidelines. World Health Organization, Geneva.

Mutyaba T, Mmiro FA, Weiderpass E (2006). Knowledge, attitudes and practices on cervical cancer screening among the medical workers of Mulago Hospital, Uganda. BMC Med. Educ. 6(1):13.

Nasiell K, Roger V, Nasiell M (1986). Behavior of mild cervical dysplasia during long-term follow-up. Obstet. Gynecol. 67(5):665-669.

Oche MO, Kaoje AU, Gana G, Jessica JT (2013). Cancer of the cervix and cervical screening: Current knowledge, attitude and practices of female health workers in Sokoto, Nigeria. Int. J. Med. Med. Sci. 5:184-190.

Parkin DM, Whelan SL, Ferlay J, Storm H (2005). Cancer Incidence in Five Continents. IARC Cancer Base No. 7:I-VIII.

Sankaranarayanan R, Budukh AM, Rajkumar R (2001). Effective screening programmes for cervical cancer in low- and middle-income developing countries. Bull. World Health Organ. 79(10):954-962.

Serraino D, Dal Maso L, La Vecchia C, Franceschi S (2002). Invasive cervical cancer as an AIDS-defining illness in Europe. AIDS 16(5):781-786.

Terefe Y, Gaym A (2008). Knowledge, attitude and practice of screening for carcinoma of the cervix among reproductive health clients at three teaching hospitals, Addis Ababa, Ethiopia. Ethiop. J. Reprod. Health 2(1):11.

WHO (2004). World Health Report 2004. Geneva, World Health Organization.

WHO/ICO (2010). Information Centre on HPV and Cervical Cancer (HPV Information Centre) "Human Papillomavirus and Related Cancers in World. Summary Report 2009."

Wong LP, Wong YL, Low WY, Khoo EM, Shuib R (2009). Knowledge and awareness of cervical cancer and screening among Malaysian women who have never had a Pap smear: a qualitative study. Singapore Med. J. 50(1):49-53.

World Health Organization (WHO) (2002). Comprehensive cervical cancer control: A guide to essential practice. Screening for cervical cancer. Geneva, WHO Press.

Wright KO, Faseru B, Kuyinu YA, Faduyile FA (2011). Awareness and uptake of the Pap smear among market women in Lagos, Nigeria. J. Public Health Afr. 2(1):e14.

Wright KO, Kuyinu YA, Faduyile FA (2010). Community education on cervical cancer amongst market women in an urban area of Lagos, Nigeria. Asian Pac. J. Cancer Prev. 11(1):137-140. 